\title{
Efficacy of eco-friendly non-toxic indigenous organic preparation on germination ability, seedling length, seedling vigour, field emergence and seed mycoflora of Redgram (Cajanus cajan L.)
}

\section{Suresh Dhapke ${ }^{1}$, Sanjiv Charjan ${ }^{1}$, Ashish Lambat ${ }^{2}$ Rajesh Gadewar ${ }^{2}$}

${ }^{1}$ Dr. PDKV's College of Agriculture, Nagpur, M. S. India

${ }^{2}$ Sevadal Mahila Mahavidyalaya and Research Academy, Nagpur, M. S. India. Corresponding Author : lambatashish@gmail.com

\section{ABSTRACT:}

Quality of seeds is very important for any crop to grow better in the future and to give higher yield and also to grow vigorously. These could also enhanced by treating with many poisonous chemicals and growth factors. But these are always hazardous to human being, animals, microorganisms, environment and natural habitats. There are some facts like, if the crops are grown under the indigenous organic preparation, cultivation are less prone to diseases attack and safe to health. In the view of the above facts, the present study was conducted to evaluate the effect of different organic preparation which were indigenously prepared on seed quality parameters of redgram viz., germination percentage, length of plumule, length of radicals, seedling dry weight, seedling vigour, field emergence percentage of mycoflora. The results revealed that the seeds soaked in Brahamastra showed significantly highest germination percentage, length of plumule, length of radicals, seedling dry weight, seedling vigour, field emergence percentage and lesser invasion of mycoflora followed by Beejamrutha, Panchgavya and Jeevamrutha. The control which was soaking in water recorded significantly lowest seed quality parameters and highest invasion of mycoflora.

Keywords: Germination percentage, Length of plumule, Length of radicals, Seedling dry weight, Seedling vigour, Field emergence percentage, redgram.

\section{INTRODUCTION:}

Pulse crop are major source of oil, protein, minerals and vitamins and forms important part of predominantly vegetarian diet of Indian people. Among all grain legumes redgram is the most important kharif crop as it is most suitable for intercropping system. The modern agriculture depends more on chemicals which cause several environmental concerns as well as hazardous to human beings, livestocks. Such concerns and problems posed by modern 
agriculture paved with the way of rebirth to organic farming. Moreover since behind organic farming is to cultivate crops with environmental harmony, enhance soil fertility, promote soil biota, manage pests, diseases and weeds in eco-friendly manner and promote livestock and human health. In view of the above facts, the present investigation was therefore initiate to study the efficacy of indigenous organic preparation on germinability, seedling length seedling vigour, field emergence and mycoflora of redgram.

\section{MATERIAL AND METHOD:}

The laboratory and field experiments were carried out during 2012 in Department of Agricultural Botany, College of Agriculture, Nagpur. Seeds of redgram were treated with four organic preparation viz. Brahamastra, Beejamrutha, Panchgavya and Jeevamrutha. The efficacy was compared with control (water) by studying germinability, seedling length, seedling vigour, field emergence and seed mycoflora.

\section{Methodology of Beejamrutha preparation}

Cow dung (50 g) was taken in cotton cloth and tied firmly and clipped in a glass beaker 1 litre of water overnight. Meanwhile lime solution was prepared bydissolving 1.2 gin $25 \mathrm{ml}$ of water.next day morning, lime solution and $125 \mathrm{ml}$ of cow urine were poured in to the glass beaker. Mixture was stirred well for proper mixing and solution is applied to soybean seeds.(Swamy, 2006a).

\section{Methodology of Jeevamrutha preparation}

This organic preparation was made bymixing $250 \mathrm{~g}$ cowdung, $250 \mathrm{ml}$ cow urine, $50 \mathrm{~g}$ jiggery, $50 \mathrm{~g}$ gram flour, $2 \mathrm{~g}$ farm soil mixed well with 5litre water in a plastic barrel. Barrel was kept in shade for one week undisturbed. It was stirred in anticlockwise direction daily twice and solution is applied to soybean seeds.(Swamy,2006b). 


\section{Methodology of Panchagavya preparation}

This organic preparation was made by mixing $50 \mathrm{ml}$ cow milk, $50 \mathrm{ml}$ curd, $25 \mathrm{ml}$ ghee, $70 \mathrm{ml}$ cow urine and $125 \mathrm{ml}$ fresh dung slurry in wide mouthed vessel and was kept in shady place. The solution was stirredev jiggery, $50 \mathrm{~g}$ gram flour, $2 \mathrm{~g}$ farm soil mixed well everyday during morning and evening. The panchagavya solution was ready on ninth day and it was applied to soybean seeds. (Swamy,2006c).

\section{Methodology Brahamastra preparation}

This organic preparation made by mixing $100 \mathrm{ml}$ cow urine, $30 \mathrm{~g}$ cow dung,30g neem leaves, $20 \mathrm{~g}$ castor leaves, $20 \mathrm{~g}$ lakki (kalatropis sp.) leaves, $20 \mathrm{~g}$ custard apple leaves,20 g parthnium leaves, $10 \mathrm{~g}$ pongamia and $10 \mathrm{~g}$ bitter gourd in 2 litre of water in a container. After this contents in this container were boiled and were kept for 30 days for fermentation. After filtration, the solution was used to apply to soybean seeds.

The above four solution (treatment) were used to soak redgram seeds for 5 minutes and were followed two minutes shade drying and about 100 seeds were used to inculcate in blotting paper for all the solution treatments separately in four replication for determining seed germinability percentage (germination percent). The germination percentage was evaluated on the value for percent normal seedling (Anonymous, 1985). The seedling vigour index was workout following the method of Abdul- Baki and Anderson (1973). The fungal flora of the redgram seeds were detected by the standard moist blotter and agar medium techniques as prescribed by international rules for seedtesting(Anonymous, 1985). The different type of fungal growth on the seed were expressed in percentage.

\section{RESULTS AND DISCUSSION:}

Data presented in the Table 1 showed that brahmastra was significantly superior over other treatments, where $85 \%$ germination was observed and recorded highest seedling vigour index (3570) followed by Jeevamrutha with $81 \%$ germination and seedling vigour index (3159). Panchgavhya recorded 
germination $77 \%$ with seedling vigour index (2772) followed by Beejamrutha which recorded $73 \%$ germination with (2190). The control seed which only plain water application recorded lowest germination of $71 \%$ with seedling vigour index of (1917). It is clear from the present investigation that the seeds of Brahmastra treatment was found to be significantly superior with $85 \%$ and seedling vigour index 3570 than Jeevamrutha, Panchgavya, Beejamrutha and control. This must be due to Brahmastra solution which contain plant and animal products having anti-pathogenic properties. It protects the redgram seeds from seed born pathogens which could affect them during the germination processes. Cow dung and cow urine would provide the nutrition for seeds which could give good germination and seedling length. The similar results were also reported by Jahagirdar et al. (2001), Sugha (2005), Sumangala (2007), Shridhar et al. (2011) and Gadewar et al. (2013).

Table 1: impact of organic preparation ( treatment on seed germination per cent, length of seedling $(\mathrm{cm})$, seedling vigour index (svi) and field emergence (percent).

\begin{tabular}{|l|l|l|l|l|l|}
\hline Sr. No. & $\begin{array}{l}\text { Treatments } \\
\text { (Organic } \\
\text { preperation) }\end{array}$ & $\begin{array}{l}\text { Mean } \\
\text { germination } \\
\text { (Percent) }\end{array}$ & $\begin{array}{l}\text { Mean } \\
\text { length of } \\
\text { seedling(cm) }\end{array}$ & $\begin{array}{l}\text { Mean } \\
\text { seedling } \\
\text { vigour } \\
\text { Index }\end{array}$ & $\begin{array}{l}\text { Mean field } \\
\text { emergence } \\
\text { percent }\end{array}$ \\
\hline 1 & Beejamrutha & 73 & 30 & 2190 & 63 \\
\hline 2 & Jeevamrutha & 81 & 39 & 3159 & 71 \\
\hline 3 & panchgavya & 77 & 36 & 2772 & 66 \\
\hline 4 & Brahmastra & 85 & 42 & 3570 & 77 \\
\hline 5 & Control & 71 & 27 & 1917 & 61 \\
\hline & SE \pm & 0.94 & 0.21 & ---- & 0.99 \\
\hline & CD at $1 \%$ & 3.81 & 0.84 & ---- & 4.00 \\
\hline
\end{tabular}

Field emergence confirmed the superiority of Brahmastra (77 percent) over the Jeevamrutha (71 percent), Panchgavhya ( 66 percent), Beejamrutha (63 percent) and Control ( 61 percent). This might be due to the high seedling vigour 
index. Bhardwaj (1995) and Bansal (2011) reported that animal waste product improve the soil physical conditions and environmental quality as well as provides nutrient for plants.

It might be seen from Table 2 that species of Alternaria, Aspergillus, Cladosporium, Currvularia,Fusarium, Penicillium and Rhizopus were isolated from the seeds of redgram. The incidence percentage of isolated fungal flora was higher in control. The Brahmastra treatment provided much protection to redgram seeds in preventing the development of fungal colonies both quantitative and specieswise as compared to Panchgavya, Jeevamrutha and Beejamrutha treatments. This might be due to anti-pathogenic properties of plant and animal products of brahmastra. The results obtained were in conformity with the findings of Bhaskara (1994), Jahagirdar et al. (2001), Sumangala (2007), Mane et al. (2001), Gadewar et al.(2013)

Table-2: Impact of organic preparation on incidence percentage of microflora on redgram seeds.

\begin{tabular}{|c|c|c|c|c|c|c|c|c|c|c|c|c|c|c|c|}
\hline \multirow{3}{*}{$\begin{array}{l}\text { Sr. } \\
\text { No. }\end{array}$} & \multirow{3}{*}{$\begin{array}{l}\text { Treatments } \\
\text { (organic } \\
\text { Preperation) }\end{array}$} & \multicolumn{14}{|c|}{ Percentage of fungi encountered on soybean seeds } \\
\hline & & \multicolumn{2}{|c|}{$\mathbf{A}$} & \multicolumn{2}{|c|}{ B } & \multicolumn{2}{|c|}{$\mathbf{C}$} & \multicolumn{2}{|c|}{ D } & \multicolumn{2}{|c|}{$\mathbf{E}$} & \multicolumn{2}{|c|}{$\mathbf{F}$} & \multicolumn{2}{|c|}{ G } \\
\hline & & 1 & 2 & 1 & 2 & 1 & 2 & 1 & 2 & 1 & 2 & 1 & 2 & 1 & 2 \\
\hline 1 & Beejamrutha & 2 & 30 & 4 & 28 & 6 & 22 & 3 & 30 & 3 & 29 & 4 & 39 & 2 & 19 \\
\hline 2 & Jeevamrutha & 2 & 21 & 4 & 30 & 3 & 28 & 1 & 10 & 2 & 21 & 2 & 25 & 1 & 6 \\
\hline 3 & Panchgavya & 2 & 19 & 5 & 39 & 2 & 22 & 2 & 18 & 2 & 23 & 3 & 26 & 2 & 14 \\
\hline 4 & Brahmastra & 1 & 4 & 2 & 8 & 1 & 4 & 1 & 6 & 1 & 4 & 2 & 12 & 1 & 6 \\
\hline 5 & Control & 5 & 36 & 14 & 64 & 4 & 33 & 5 & 42 & 6 & 35 & 7 & 57 & 3 & 27 \\
\hline
\end{tabular}

A: Alterneria sp; B: Aspergillus sp; C: Cladosporium sp; D: Curvularia $s p$; E: Fusarium sp; F: Penicillium sp; G: Rhizopus sp; 1: Standard blotter paper method; 2: Agar plate method. 


\section{CONCLUSION:}

Thus from the present study, it can be concluded that seeds of redgram should be treated (soaked) with Brahmastra solution before sowing. Because this treatment showed significantly maximum germination percent, length of seedling, seedling vigour index, field emergence percent and minimum invision of fungal flora on the redgram seeds.

\section{REFERENCES:}

Abdul-Baki, A.A. and Anderson, J.D.1973. Vigour determination in soybean seed by multiple criteria.Crop Sci. 13: 630-633

Anonymous. 1985. International rules for seed testing. Seed sci. and Technol.4:299-513.

Bansal, Amrit Kaur 2011. Effect of different (cattle poultry-horse and goat dung) on nutritional status of vermicompost.Green farming 2:114-115

Bhaskara, Padmodaya.1994. Biological control of seedling disease and wilt in tomato caused by Fusarium oxysporium. Unpublished Ph. D.Thesis, University Agric. Sci. Bangalore, India.

Bharadwaj, K.K.R. 1995. Recycling of crop residues oilcakes and other plant products in agriculture. In: Tandon, HLS, Editor. 1995. Recycling of crop, animals, human and industrial waste in agriculture. Fertilizer development and consultation organzation, New Delhi, PP 9-30.

Gadewar, R., Lambat, A., and Charjan., S. 2013. Efficacy of indigenous organic preparation on viability, vigour, field emergence and seed mycoflora of Mungbean. In: Sustainable approaches for environmental conservation, pp 31-35, Khanna, D.R., Chopra, A. K., Bhutiani., matta gagan and Vikas Singh (Eds.), Biotech Books, New Delhi (Book Chapter). 
Jahagirdar shamrao, Siddaramaiah, A.L. and Ramaswamy, G.R. (2001). Influence of biocontrol agent and MPG-3 on Fusarium oxysporium.

Mane, V.A.,V.A., Belwadkar, V. N. Gawade, B.V. Medhe, N. K. and Randive, S.N. (2001) In vitro evaluation of bio-agents and botanicals against alterneria leaf blight of chilli. Green Farming .Z : 97-98.

Sugha, S.K. (2005). Antifungal potential of Panchagavya. Pl. Dis. Res. 20: 156- 158.

Swamy, Anand. (2006) a.Preparation of Beejamrutha, In: Subhash Palekarara Shoonya Bandavalada Naisargika Krushi(LocallLanguage), 8 th Ed. published by Agni Prakashana, Bangalore,India, P: 8-9.

Swamy, Anand. (2006 b).Preparation of Jeevamrutha, In: Subhash Palekarara Shoonya Bandavalada Naisargika Krushi(LocallLanguage), 8 th Ed. published by Agni Prakashana, Bangalore,India, P:13-20.

Swamy, Anand. (2006c) Natural pesticides,In: Subhash Palekarara Shoonya Bandavalada Naisargika Krushi(LocallLanguage), 8 th Ed. published by Agni Prakashana, Bangalore,India, P:-91-92.

Sumangala Koulagi (2007). Studies on grain discolouration in rice. Unpublished M.Sc.(Agri.) Thesis, University Agric. Sci. Dharwad.

Sridar, D. Mahanthesh, B. Patil, Sumangala Koulagi and Ravi Kumar H. S. (2011). Influence of indigenous organic preparation on germination and vigour index of paddy. Green Farrming. 2:302-304. 